Article

\title{
Suitability of Wild Phragmites australis as Bio-Resource: Tissue Quality and Morphology of Populations from Three Continents
}

\author{
Franziska Eller ${ }^{1, *}$, Xiao Guo ${ }^{2}$, Siyuan Ye ${ }^{3}$, Thomas J. Mozdzer ${ }^{4}$ and Hans Brix ${ }^{1}$ \\ 1 Department of Biology, Aarhus University, Ole Worms Alle 1, 8000 Aarhus, Denmark; hans.brix@bio.au.dk \\ 2 College of Landscape Architecture and Forestry, Qingdao Agricultural University, Qingdao 266109, China; \\ guoxiao018@163.com \\ 3 Key Laboratory of Coastal Wetland Biogeosciences, China Geological Survey, Qingdao Institute of \\ Marine Geology, CGS, MLR, Fuzhou Road 62, Qingdao 266071, China; ysiyuan@mail.cgs.gov.cn \\ 4 Bryn Mawr College, 101 N Merion Ave., Bryn Mawr, PA 19010, USA; tmozdzer@brynmawr.edu \\ * Correspondence: franziska.eller@bio.au.dk
}

Received: 30 September 2020; Accepted: 3 December 2020; Published: 7 December 2020

\begin{abstract}
We collected and analyzed morphological characteristics and tissue nutrient concentrations of common reed (Phragmites australis) populations from Denmark, USA, and China, harvested late summer at the peak of the biomass production. The aim was to estimate the suitability of the biomass for different bioenergy purposes. The potential of reed as bioenergy feedstock is increasingly recognized, as the species already is utilized for construction, water purification, and pulp production. Our morphological data showed that biomass yield can be allometrically predicted to be high, especially in the reed populations of the US. However, no consistent pattern according to geographical origin was detected, and especially tissue nutrient concentrations varied within and between populations. Some mineral concentrations were above the desirable threshold for biocombustion, such as nitrogen $(\mathrm{N})$ and sulfur $(\mathrm{S})$. Iron (Fe) was higher than the critical toxicity concentration in many populations and hence, negatively correlated with morphological and growth traits. A different harvest time is likely to result in lower ion concentrations. Some populations had low $\mathrm{C}$ to $\mathrm{N}$ ratios, which are suitable for biomethane production, while the relatively low ash content of all populations (ranging from 3.9\% to $8.5 \%$ ) suggested a high heating value and theoretical energy potential. Reed biomass production is a promising alternative to fossil fuels and potentially suitable for other bio-based product. Improved knowledge is needed to examine local needs and application possibilities for reed biomass.
\end{abstract}

Keywords: biocombustion; biomethane; nutrient concentration; paludiculture; invasive reed

\section{Introduction}

Energy is one of the main limiting, essential resources on earth faced with a growing demand and limited supply. Global challenges, such as the growing human population and the rapid consumption of finite energy sources, are issues that need to be faced with sustainable, long-term viable solutions to avoid fossil energy exhaustion [1]. One of those solutions is the utilization of renewable biomass of bioenergy crops to develop an energy sector with a low carbon footprint, fueled by bioethanol, biomethane, and biocombustion [2-4]. The specific application purpose will depend on the local energy technology and the suitability of the biomass quality and quantity.

Photosynthesis, the conversion of solar energy and atmospheric $\mathrm{CO}_{2}$ by plants into structural and non-structural carbohydrates, ultimately results in the production of biomass components including cellulose, hemicelluloses, lignin, lipids, proteins, starch, and other compounds. The concentrations of 
each class of compound varies depending on species, type of plant tissue, stage of growth, and growing conditions [5,6]. Moreover, the plant tissue contains components incorporated from soil nutrients, such as several ions and trace elements in different concentrations. The characteristics of the biomass will determine which purpose the tissue is suitable for, since different ion concentrations, ash production, and tissue composition are desirable for different application purposes [2,7]. The local conditions, such as the length of the growing season, solar radiation, precipitation, soil texture, and nutrient availability, are important influences for the plants' productivity and biomass properties [8,9]. Moreover, the timing of the harvest affects nutrient concentrations and starch retention in green tissues [10].

The source of the biomass is paramount for avoiding competition with agricultural land for food crops. A recently developed concept that is steadily growing is the utilization of natural wetland plant species to harvest biomass for energy purposes [11,12]. This concept, called paludiculture, practices the cultivation of highly productive wetland species on formerly drained, rewetted organic soil. Appropriate rewetting suppresses decomposition processes that lead to greenhouse gas emissions from drained areas, thereby decreasing the carbon footprint even further than does the use of sustainable biomass itself. Multiple studies have been dedicated to finding appropriate paludiculture crops with the desired quality and productivity for specific uses-innovative or conventional $[6,13]$.

One of the most promising, natural wetland bioenergy crops is common reed, Phragmites australis (hereafter named reed), an intensely studied, tall grass species of the Poaceae family. Reed is a cosmopolitan species with a near-global distribution and great socio-economic importance [14]. The broad scientific interest for this species results especially from its high intraspecific diversity, which is ideal for studying acclimation and adaptation processes, as well as responses to global change [9,15-18]. Reed is abundant and often the dominant species where it occurs, it grows in wet ecosystems and others that cannot clearly be recognized as wetlands, such as roadsides, ruderal areas, and shallow depressions in alpine areas $[19,20]$. The species is perennial, with culms deceasing by the end of the growing season and new shoots emerging again in spring from the overwintering belowground shoots (called rhizomes) [14]. Apart from vegetative growth, reed also reproduces sexually by seed production $[9,18]$. The species consists of several subspecies and groups, which are highly diverse with broad ecological niches and distinct stand and shoot morphology [16,21,22]. Three main phylogeographic groups are commonly distinguished within the species-the North American P. australis ssp. americanus, the East Asian/Australian group, and the Northern Hemisphere/African group, which includes European P. australis $[23,24]$. Furthermore, the physiological responses to environmental factors have been demonstrated to vary between reeds with different geographical origins $[8,25,26]$. Reed provides a long range of ecosystem services, like habitat, carbon sequestration, climate regulation, and water quality management [27]. Historically, reed has been used in northern and central Europe for thatching of roofs, fencing, insulation, and cardboard manufacturing [13,28,29], and is recognized globally as suitable species for nutrient and pollutant removal in constructed wetlands [30]. In the Liaohe River Delta in China, the largest managed reed wetland is regularly harvested for paper production [31]. While the biomass is used for paper pulp, the benefits of the wetland are maximized for ecotourism and as partly protected wetland habitat.

The large body of research done regarding the species' ecology and growth, and the fact that it is readily available at high quantity in many areas, open for the possibility of harvesting wild reeds for biomass. This is already practiced in some parts of the world, where naturally established reed wetlands are harvested, without preventing the ecosystem to proceed to exist, and maintaining its ecosystem services [31]. Utilizing natural reed biomass presupposes knowledge on the quantity and quality of the biomass in different populations, since not merely the local growing conditions, but also the genetic origin of different reed groups affects their morphology and fitness [32,33]. We therefore collected reed biomass from several natural populations in China, USA, and Denmark, to analyze and compare their tissue quality and several morphological characteristics. Reed grows abundantly in Denmark, in freshwater and saline wetlands, and is traditionally used for thatching and in phytoremediation. Both China and USA face severe challenges for energy generation, and contrary to Europe, the concept 
of paludiculture has not yet gained momentum there. In China, the paper production facilities grant perfect conditions for the initiation of biomass harvest for energy. In USA, and North America in general, a reed lineage from Europe has invaded large areas of the continent and is considered a noxious weed, which is controlled using herbicides and burning [34]. This wasteful eradication could be turned to an exploitation of the biomass for useful bioenergy processes. Our aim was to give an overview of biomass quality and morphological characteristics of representative reed populations occurring on three continents. By demonstrating that the tissue quality of those natural reed populations is within the desirable range of biomass characteristics for several bioenergy purposes, we hope that our study can inspire the initiation or expansion of reed utilization as a nature-based solution for renewable energy production.

We sampled two representative marsh locations in Denmark, two areas and several locations in the US with invasive reed, and five larger areas with several within-locations in China, including two of the major Chinese estuaries and the largest managed reed wetland in the Liaohe River Delta. We picked five shoots per population to measure different shoot growth aspects and assessed the population density, as proxies for the population productivity. We analyzed the shoots' tissue nutrient concentration, and water and ash content, which are indicative of the biomass decomposability, requirement for drying, and suitability for purposes such as anaerobic digestion. The concentrations of multiple mineral elements are presented, which may be desirable until a particular threshold value. We also determined the correlation between all measured traits, which may be useful in determining other potentially useful populations without the need to conduct all analyses prior to harvest. Populations were clustered to see if provenance was the most important aspect with respect to potential similarities between samples. We did not analyze the nutrient availability in soils, as this was out of the scope of this investigation, and the overall purpose of our study was to describe naturally growing reeds, not to aid in the manipulation of natural conditions (e.g., by fertilizer addition, which requires knowledge of the soil conditions) or to start reed cultivation.

Our study presents an initial overview of possible locations for reed utilization and will hopefully inspire a consideration of the uses of reed other than the conventional management. It will still be necessary to conduct a thorough investigation of proper harvesting time and technique, life cycle analysis, and certain biomass characteristics for any particular purpose and location, but our project is hopefully a useful starting point.

\section{Materials and Methods}

\subsection{Field Sampling Sites}

The field sites were chosen according to the following criteria: representative and dissimilar habitats, medium to large reed population size, good accessibility. Within the same location, each site was sampled at least $500 \mathrm{~m}$ apart to ensure sampling of different populations. Reed was sampled at two sites in Denmark on the mainland of Jutland, as shown in Table 1. The species is native to Europe, a part of the Northern Hemisphere/African reed group, and abundant in most freshwater wetlands and brackish marshes in Denmark. The first site was in southern Jutland in the marsh Tøndermarsken, specifically Magisterkogen (site MK). The sampled marsh is a typical example of a wet meadow within the cultural landscape of Denmark. It lies between two dikes and was ungrazed at the time of sampling, late August 2016. The reed stand was dense, the plants were flowering, and growing close to the Danish creek Vidå. The area is surrounded by intensive agriculture, mainly crops. The second Danish site was in the restored peatland of Lille Vildmose in northern Jutland, where a dense, flowering population of reed grew in a roadside ditch at the edge of a bog (site LV). Reeds were sampled at the beginning of September 2016. Lille Vildmose is the largest remaining raised bog in Northwestern Europe, consisting of pristine and reclaimed peatland. 
Table 1. Sampling sites of shoots of Phragmites australis populations. DK, Denmark; CN, China; YRD, Yellow River Delta; LRD, Liaohe River Delta; US, USA; HNR, Heinz nature reserve.

\begin{tabular}{|c|c|c|c|c|c|c|}
\hline \multirow{2}{*}{$\begin{array}{l}\text { Site } \\
\text { MK }\end{array}$} & \multirow{2}{*}{$\begin{array}{c}\text { Location } \\
\text { DK, Magisterkogen }\end{array}$} & \multicolumn{2}{|c|}{ GPS Coordinates } & \multirow{2}{*}{$\begin{array}{c}\text { Altitude (m) } \\
-1\end{array}$} & \multirow{2}{*}{$\begin{array}{c}\text { Sampling Date } \\
\text { August } 2016\end{array}$} & \multirow{2}{*}{$\begin{array}{c}\begin{array}{c}\text { Shoot Density } \\
\text { (Number of } \\
\text { Shoots } \mathbf{~ m}^{-2} \text { ) }\end{array} \\
112\end{array}$} \\
\hline & & $54^{\circ} 54^{\prime} 30^{\prime \prime} \mathrm{N}$ & $8^{\circ} 48^{\prime} 45.0^{\prime \prime} \mathrm{E}$ & & & \\
\hline LV & DK, Lille Vildmose & $56^{\circ} 53^{\prime} 31^{\prime \prime} \mathrm{N}$ & $10^{\circ} 11^{\prime} 17.4^{\prime \prime} \mathrm{E}$ & 4 & September 2016 & 110 \\
\hline FanI & $\mathrm{CN}$, Fanggan & $36^{\circ} 25^{\prime} 10.6^{\prime \prime} \mathrm{N}$ & $117^{\circ} 26^{\prime} 34.9^{\prime \prime} \mathrm{E}$ & 544 & August 2016 & 20 \\
\hline FanII & $\mathrm{CN}$, Fanggan field & $36^{\circ} 25^{\prime} 16.8^{\prime \prime} \mathrm{N}$ & $117^{\circ} 26^{\prime} 24^{\prime \prime} \mathrm{E}$ & 540 & August 2016 & 34 \\
\hline FanIII & $\mathrm{CN}$, Fanggan mountain & $36^{\circ} 25^{\prime} 25.8^{\prime \prime} \mathrm{N}$ & $117^{\circ} 27^{\prime} 27.8^{\prime \prime} \mathrm{E}$ & 486 & August 2016 & 40 \\
\hline ShI & $\mathrm{CN}$, Shandong stream & $36^{\circ} 27^{\prime} 17.6^{\prime \prime} \mathrm{N}$ & $117^{\circ} 29^{\prime} 15.5^{\prime \prime} \mathrm{E}$ & 266 & August 2016 & 70 \\
\hline ShII & $\mathrm{CN}$, Shandong shore & $36^{\circ} 27^{\prime} 13.9^{\prime \prime} \mathrm{N}$ & $117^{\circ} 30^{\prime} 34.7^{\prime \prime} \mathrm{E}$ & 246 & August 2016 & 80 \\
\hline ShIII & $\mathrm{CN}$, Shandong floodplain & $36^{\circ} 27^{\prime} 13.3^{\prime \prime} \mathrm{N}$ & $117^{\circ} 30^{\prime} 30.6^{\prime \prime} \mathrm{E}$ & 246 & August 2016 & 80 \\
\hline EM & $\mathrm{CN}$, Elkmarsh & $33^{\circ} 3^{\prime} 0.7^{\prime \prime} \mathrm{N}$ & $120^{\circ} 48^{\prime} 59^{\prime \prime} \mathrm{E}$ & 10 & September 2016 & 48 \\
\hline YRDI & CN, YRD Reserve & $37^{\circ} 45^{\prime} 49^{\prime \prime} \mathrm{N}$ & $119^{\circ} 2^{\prime} 5.9^{\prime \prime} \mathrm{E}$ & 9 & September 2016 & 90 \\
\hline YRDII & CN, YRD Reserve Tidal creek & $37^{\circ} 46^{\prime} 38.4^{\prime \prime} \mathrm{N}$ & $119^{\circ} 5^{\prime} 13.1^{\prime \prime} \mathrm{E}$ & 9 & September 2016 & 136 \\
\hline YRDIII & CN, YRD Reserve border & $37^{\circ} 50^{\prime} 1.5^{\prime \prime} \mathrm{N}$ & $119^{\circ} 2^{\prime} 17.4^{\prime \prime} \mathrm{E}$ & 5 & September 2016 & 106 \\
\hline DW & CN, Dongwang & $37^{\circ} 47^{\prime} 34.4^{\prime \prime} \mathrm{N}$ & $118^{\circ} 26^{\prime} 18.8^{\prime \prime} \mathrm{E}$ & 18 & September 2016 & 82 \\
\hline Oil & CN, YRD oil field & $38^{\circ} 2^{\prime} 44.8^{\prime \prime} \mathrm{N}$ & $118^{\circ} 40^{\prime} 39.7^{\prime \prime} \mathrm{E}$ & -0.5 & September 2016 & 56 \\
\hline LRDI & CN, LRD boardwalks & $40^{\circ} 57^{\prime} 39.2^{\prime \prime} \mathrm{N}$ & $121^{\circ} 48^{\prime} 10.8^{\prime \prime} \mathrm{E}$ & -2 & August 2017 & 40 \\
\hline LRDII & $\mathrm{CN}, \mathrm{LRD}$ road & $40^{\circ} 59^{\prime} 51.9^{\prime \prime} \mathrm{N}$ & $121^{\circ} 50^{\prime} 7.4^{\prime \prime} \mathrm{E}$ & -2 & August 2017 & 50 \\
\hline LRDIII & CN, LRD road north & $41^{\circ} 0^{\prime} 16.4^{\prime \prime} \mathrm{N}$ & $121^{\circ} 50^{\prime} 41.4^{\prime \prime} \mathrm{E}$ & -3 & August 2017 & 62 \\
\hline HNRI & US, HNR Darby Township & $39^{\circ} 53^{\prime} 19.4^{\prime \prime} \mathrm{N}$ & $75^{\circ} 15^{\prime} 41.4^{\prime \prime} \mathrm{W}$ & 7 & July 2017 & 52 \\
\hline HNRII & US, HNR fishing platform & $39^{\circ} 52^{\prime} 49.6^{\prime \prime} \mathrm{N}$ & $75^{\circ} 15^{\prime} 55^{\prime \prime} \mathrm{W}$ & 2 & July 2017 & 46 \\
\hline HNRIII & US, HNR Tinicum Township & $39^{\circ} 52^{\prime} 37.8^{\prime \prime} \mathrm{N}$ & $75^{\circ} 16^{\prime} 40.8^{\prime \prime} \mathrm{W}$ & 2 & July 2017 & 50 \\
\hline HNRIV & US, HNR Darby Creek & $39^{\circ} 52^{\prime} 28.3^{\prime \prime} \mathrm{N}$ & $75^{\circ} 17^{\prime} 43^{\prime \prime} \mathrm{W}$ & 2 & July 2017 & 48 \\
\hline PHL & US, ruderal wetland & $39^{\circ} 52^{\prime} 20.2^{\prime \prime} \mathrm{N}$ & $75^{\circ} 16^{\prime} 30.5^{\prime \prime} \mathrm{W}$ & 1 & August 2017 & 70 \\
\hline
\end{tabular}

Reeds were collected in China over two consecutive years, 2016 and 2017. The species is native in Asia, predominantly belonging to the East Asian/Australian group. Although P. australis from the European Northern hemisphere group extends to Asia, and hybrids with other Phragmites species occur in that area, there is so far no evidence of an undetected (cryptic) invasion of non-native lineages in East China [35]. Most collected shoots had flowers, except the ones from Fanggan mountains and river. In early August 2016, reed populations were sampled from three sites in Fanggan mountains in Laicheng District, Shandong Province, China. The populations were found in sparse stands in a mountain valley with extensive farming of different vegetables (site FanI), as shown in Table 1, close to a temporary creek (site FanII), and close to a road near a lake (site FanIII). Populations were also collected along the floodplains (sites ShI, ShII, and ShIII) on both sides of the river. In late September 2016, a population was sampled close to Dafeng and Yancheng City, Liangdoncun, in a protected marsh dominated by reed, where rewilded moose are used for marsh management (site EM). The area has a temperate monsoon climate with an annual mean temperature of $14.4^{\circ} \mathrm{C}$ and a mean annual precipitation of $1005 \mathrm{~mm}$. Moreover, samples were collected from the Yellow River Delta (YRD) Nature Reserve (sites YRDI, YRDII, and YRDIII), Kenli District, Shandong, China. The YRD has a warm-temperate and continental monsoon climate with a mean annual temperature of $12.9^{\circ} \mathrm{C}$ and a mean annual precipitation of $560 \mathrm{~mm}$. The soil varies from fluvo-aquic to saline and the texture is predominantly sandy clay loam [36]. Two populations were sampled outside the Nature Reserve in Lijin County close to a village on a ruderal site next to agricultural fields (site DW), and in Hekou District near salt extraction sites and oil fields in a heavily impacted area (site Oil).

In mid-August 2017, reeds were sampled from three locations in the Liaohe River Delta (LRD), Liaoning Province, from within the managed reed fields close to a boardwalk area and adjacent roads (sites LRDI, LRDII, and LRDIII). The LRD encompasses the world's largest reed field, most of which is used for paper production. The wetlands are managed by freshwater diversion from the Liaohe River to the tidal wetlands to achieve desalinization, while agriculture and oil and gas mining are impacting the Delta [37].

Reeds were collected in Pennsylvania, USA, close to Philadelphia in John Heinz National Wildlife Refuge at Tinicum adjacent to Delaware River, in late July 2017, as shown in Table 1. All stands in the refuge belonged to the invasive European-type reed lineage and not the native American reed 
subspecies, which was established by morphological determination [38]. Four sites were sampled, in a non-tidal impoundment close to Darby Township, at a fishing platform, close to a trail, and from a tidal freshwater marsh (sites HNRI to HNRIV). The Refuge has a diversity of habitats including open water, mudflats, woodlands, and freshwater tidal marsh with a tidal influence of $1.8 \mathrm{~m}$. In early August 2017, shoots were collected from a large accidental wetland on a ruderal field close to Philadelphia Airport (site PHL). All US reeds were starting to flower at the time of sampling, and based on their distinct morphology, belonged to the invasive lineage introduced from Europe [39].

\subsection{Morphological Measurements}

At each site, five healthy shoots, distanced by several meters, were chosen and cut at $\sim 10 \mathrm{~cm}$ over the soil surface. The stands generally were of uniform height except for newly emerged shoots at the edge of the stand. We collected mature, tall green shoots from the center of the stand. All shoots were starting to flower and thus at the peak of biomass production of the sampling year. The age of the shoots can be estimated to several months. The height of each shoot was measured, and the number of leaves counted. The diameter at the bottom of each of the collected stems was measured with a digital caliper. The leaves were cut from the stem and leaf and stem fresh weight was assessed separately with a portable field weight with a precision of $0.001 \mathrm{~g}$ (Scout Pro Balance, SPU123, OHAUS, Parsippany, NJ, USA). The plant tissue was then oven-dried at $80^{\circ} \mathrm{C}$ until a constant dry weight could be noted. The water content (amount of water in tissue relative to its dry weight) was calculated as mass of water per dry mass of stem or leaf, from the difference between fresh and dry weight, divided by the dry weight of the respective fraction.

\subsection{Relative Leaf Water Content}

Three to five young but fully developed healthy leaves were cut from additional shoots, and their fresh weight was measured. The leaves were then immersed in water for 3 to $4 \mathrm{~h}$ in darkness until rehydration, and the resulting turgid weight was measured. Thereafter, the leaves were dried at $80{ }^{\circ} \mathrm{C}$ until constant dry weight. The relative water content (RWC) was calculated as the ratio between the difference of fresh and dry weight, and the difference of turgid and dry weight [40,41].

\subsection{Shoot Ion, Carbon, and Nitrogen Concentrations}

The dried leaves and stems from the collected shoots were ground with a ball mill to measure the tissue concentrations of phosphorus $(\mathrm{P})$, potassium $(\mathrm{K})$, calcium $(\mathrm{Ca})$, magnesium $(\mathrm{Mg})$, sulfur (S), silicon ( $\mathrm{Si})$, iron (Fe), manganese (Mn) and sodium (Na), aluminum (Al), and zinc (Zn). About $500 \mathrm{mg}$ of the dried plant material was digested with $4 \mathrm{~mL} \mathrm{HNO}_{3}$ and $2 \mathrm{~mL} \mathrm{H}_{2} \mathrm{O}_{2}$ mixtures in a Multiwave 3000 microwave digestion system (Anton Paar, Austria). The digestions were diluted up to $50 \mathrm{~mL}$ with ultra-purified water, and the ion concentrations of the solutions were determined by inductively coupled plasma-optical emission spectrometry (ICP-OES; iCAP 7000, Thermo Scientific, Cambridge, UK) equipped with an auto-sampler. Blank digestions without plant samples were prepared doing the full analytical procedure. Certified reference material (tomato leaves) was used to ensure the quality of the analytical procedures. Total carbon $(\mathrm{C})$ and nitrogen $(\mathrm{N})$ concentrations were analyzed using an elemental analyzer (Vario EL Cube, Elementar Analysensysteme GmbH, Langenselbold, Germany). The average of two technical replicates was analyzed as sample replicate for every ion and elemental concentration.

\subsection{Shoot Ash Concentration and Loss on Ignition}

The ground leaves and stems from the collected shoots were first weighed after drying at $105^{\circ} \mathrm{C}$ for $24 \mathrm{~h}$ and then after drying in a muffle oven at $550{ }^{\circ} \mathrm{C}$ for $24 \mathrm{~h}$. The average of two technical replicates was analyzed as sample replicate. Loss on ignition was determined as the difference of the dried weight at $105^{\circ} \mathrm{C}$ and $550{ }^{\circ} \mathrm{C}$, relative to the dried weight at $105^{\circ} \mathrm{C}$. The ash content was the residual percentage of a sample, after the loss on ignition was subtracted. 


\subsection{Statistical Data Treatment}

Data were analyzed in Statgraphics Centurion XVII (Statgraphics Technologies, Inc., The Plains, VA, USA). All parameters were tested for variance homogeneity using Levene's test. Homoscedastic data were analyzed by one-way analysis of variance, to test whether the different origin of samples affected the data. Bonferroni's post-hoc test was used to identify significant differences between means of samples from different origins. If homoscedasticity was not achieved by transformation, a Kruskal-Wallis test was performed, followed by post-hoc testing with $95 \%$ Bonferroni intervals.

Spearman rank correlations were performed on all measured parameters (excluding calculated ratios) to identify significant correlations between tissue and plant characteristics in a quantitative way. For a qualitative exploration of associations between the measured parameters and the geographical origin of the biomass, hierarchical cluster analysis was done with Ward's minimum variance method, based on squared Euclidian distances on standardized means [42].

\section{Results}

\subsection{Shoot Morphology and Biomass}

Stem height, number of leaves per stem, stem diameter, and leaf and stem biomass significantly differed between samples from different provenances $(p<0.001)$. The tallest shoots with the highest biomass and number of leaves, as well as the largest shoot diameter, occurred in the US nature reserve and ruderal wetland, although the variation between those samples was rather large, as shown in Figure 1. Reeds from China, specifically the Yellow River Delta, were among the shortest with the lowest biomass, followed by the somewhat taller reeds from Denmark. Samples from China and Denmark were overall thinner (low shoot diameter) and had fewer leaves than those from the US.

\subsection{Shoot Ash Concentration and Biomass Water Content}

Water content of leaves and stems and ash concentration differed significantly between provenances $(p<0.001)$, but the variation within each population was large and overlapping, as shown in Figure 2 . The highest water content was found in reed samples from Shandong and Fanggan. The ash concentration was highly variable among samples and means ranged from 4 to $8.5 \%$. Although the relative water content of leaves (RWC) was significantly different between reed samples $(p<0.01)$, those differences were small and the leaves almost fully hydrated. The clearest difference was between all samples and the one from Lille Vildmose, Denmark, which had the lowest RWC of 0.87 , as shown in Figure 2.

\subsection{Shoot Ion, Carbon, and Nitrogen Concentrations}

The shoot carbon $(\mathrm{C})$ and nitrogen $(\mathrm{N})$ concentration differed significantly among samples from different provenances $(p<0.001)$. Nonetheless, mean shoot $C$ was relatively stable, ranging from 44 to $47 \%$, with the higher $\mathrm{C}$ concentration in US locations, as shown in Figure 3. Shoot $\mathrm{N}$ concentration was highest in Fanggan and along Shandong stream and floodplain, and lowest in the Liaohe River Delta and parts of the Yellow River Delta. All macronutrients in shoots ( $, \mathrm{P}, \mathrm{Mg}, \mathrm{Ca}, \mathrm{K}$ ) differed significantly between provenances $(p<0.001)$. The samples varied more among provenances than among continental areas, but samples from Fanggan were amongst those with the highest, while samples from Liaohe River Delta and Denmark were amongst those with the lowest nutrient concentrations, as shown in Figure 4 . The trace elements $\mathrm{Si}, \mathrm{Zn}, \mathrm{Al}, \mathrm{Na}, \mathrm{Mn}$, and $\mathrm{Fe}$ also varied significantly with provenance $(p<0.001)$. Fe concentrations were overall higher in Chinese populations and Lille Vildmose than in US populations and Magisterkogen, as shown in Figure 5. Mn concentrations were low except in samples from Magisterkogen and Liaohe River Delta. Al concentrations were highest in China, especially in the Yellow River Delta and oil fields, while US and Danish samples were close to detection limit. US reed populations had highest shoot $\mathrm{Zn}$ and $\mathrm{Si}$ concentrations, but were among the lowest concentrations for Na. The Danish samples from Lille Vildmose had relatively high Na and Zn concentrations, while those 
from Magisterkogen had high Si concentration. The Chinese samples had the highest Na concentration, except from Fanggan and Shandong.
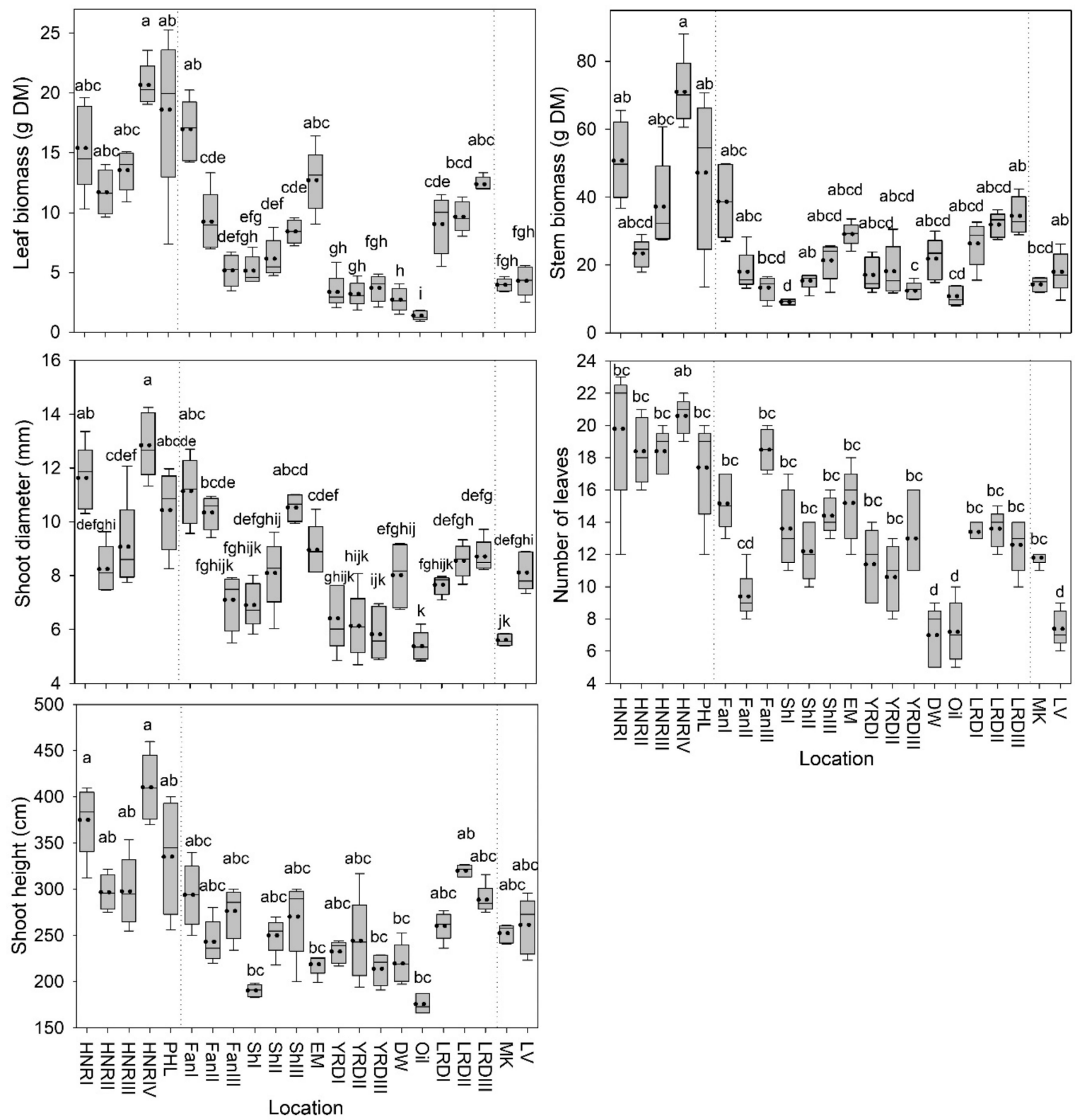

Figure 1. Leaf and stem biomass, shoot diameter, and height and number of leaves of P. australis harvested in different provenances (left group from USA, center group from China, right group from Denmark). Boxplots with 25th to 75th percentile in box, whiskers with minimum and maximum values, median as solid line, and means indicated by stippled line $(n=5)$. Different lowercase letters indicate statistically significant differences according to $95 \%$ Bonferroni intervals. 

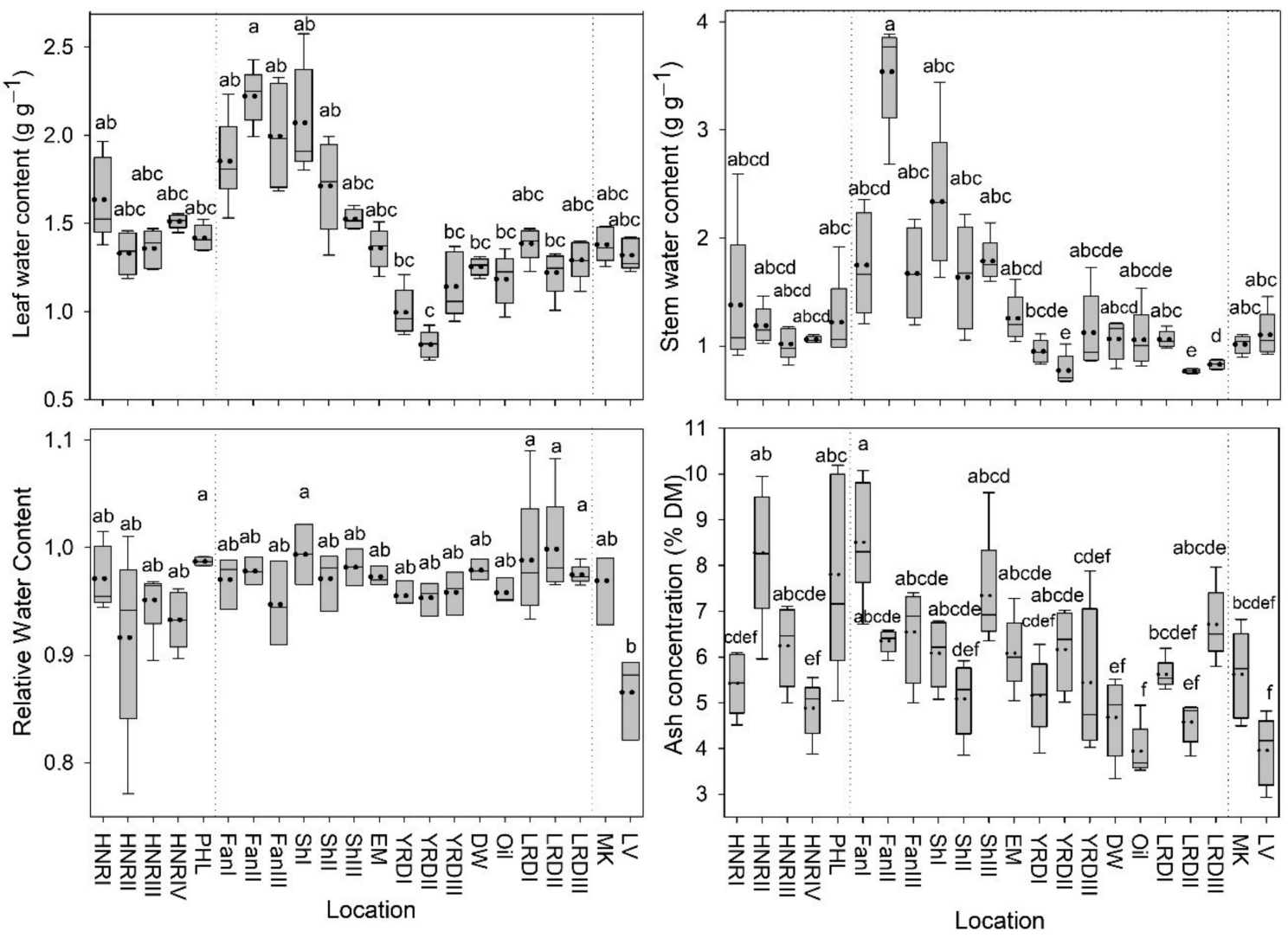

Figure 2. Leaf and stem water content, relative water content of leaves, and shoot ash concentration of $P$. australis harvested in different provenances (left group from USA, center group from China, right group from Denmark). Boxplots with 25th to 75th percentile in box, whiskers with minimum and maximum values, median as solid line, and means indicated by stippled line $(n=5$, for relative water content (RWC) $n=3$ to 5). Different lowercase letters indicate statistically significant differences according to $95 \%$ Bonferroni intervals.
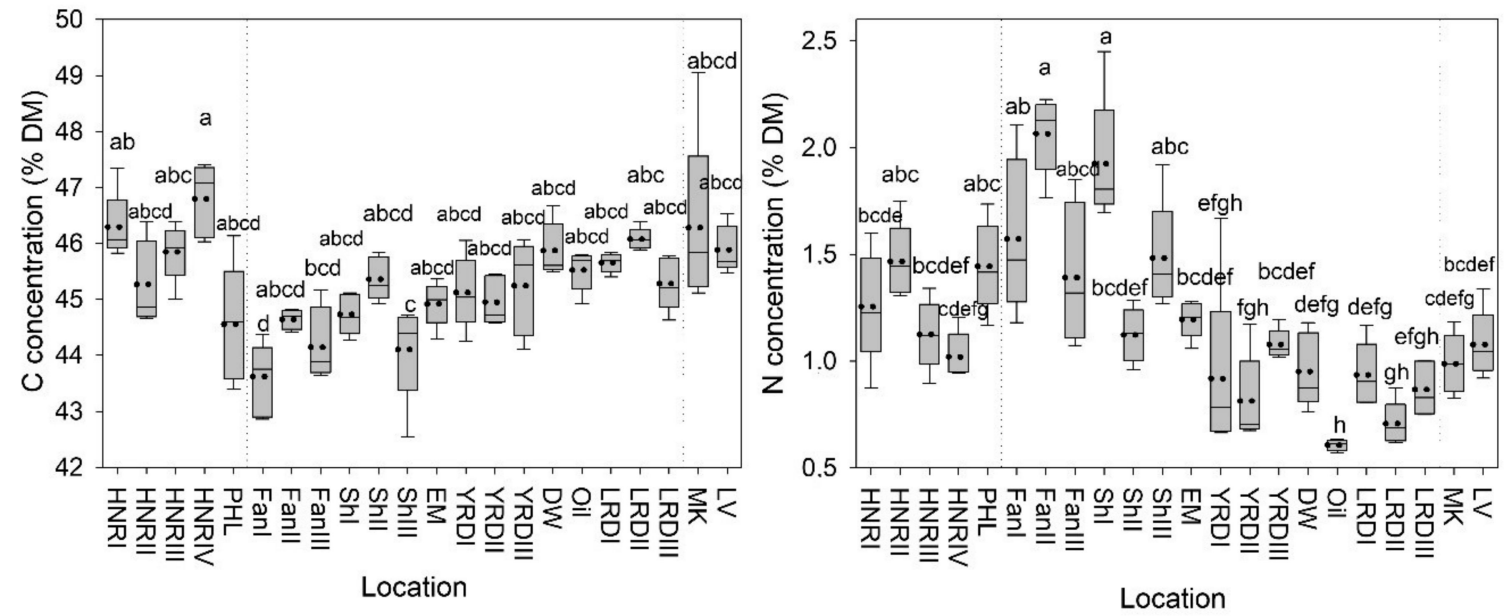

Figure 3. Shoot carbon $(\mathrm{C})$ and nitrogen $(\mathrm{N})$ concentration of P. australis harvested in different provenances (left group from USA, center group from China, right group from Denmark). Boxplots with 25 th to 75 th percentile in box, whiskers with minimum and maximum values, median as solid line, and means indicated by stippled line $(n=5)$. Different lowercase letters indicate statistically significant differences according to $95 \%$ Bonferroni intervals. 

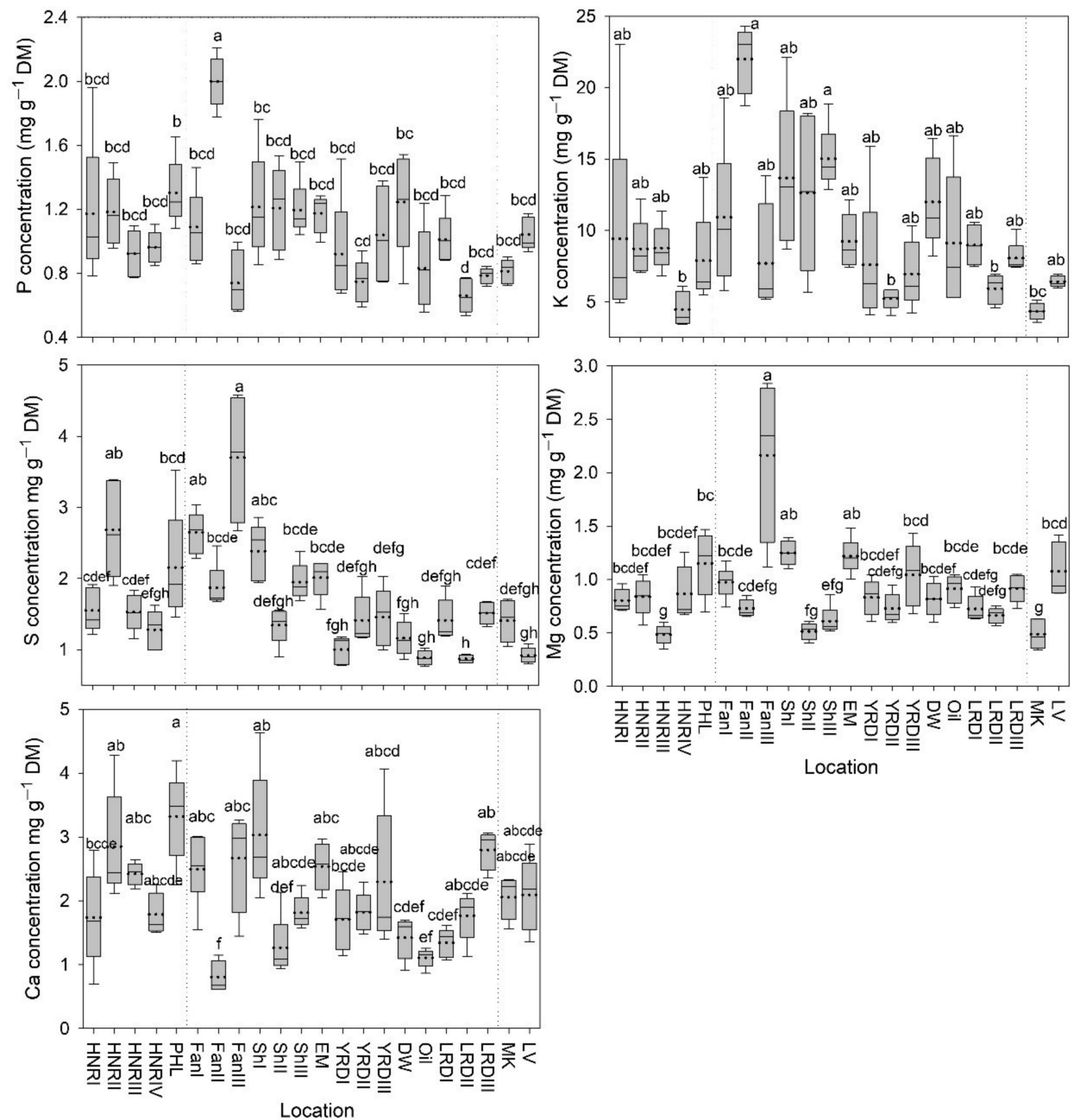

Location

Figure 4. Shoot phosphorus (P), potassium (K), sulfur (S), magnesium (Mg), and calcium (Ca) concentration of $P$. australis harvested in different provenances (left group from USA, center group from China, right group from Denmark). Boxplots with 25th to 75th percentile in box, whiskers with minimum and maximum values, median as solid line, and means indicated by stippled line $(\mathrm{n}=5)$. Different lowercase letters indicate statistically significant differences according to $95 \%$ Bonferroni intervals.

\subsection{Correlation between Parameters and Hierarchical Clustering}

Hierarchical clustering revealed two major groups (clusters) consisting of, respectively, two and one subgroup, as shown in Figure 6. The first subgroup clustered into US populations and the Chinese populations from Fanggan and Shandong floodplain, as well as Elkmarsh and the road north of Liaohe River Delta. As a sister group to those subclusters, the Chinese populations from Fanggan field, mountain, and Shandong stream appeared. The second major cluster consisted of the rest of the Chinese populations, and the two Danish populations, which clustered in sister groups. 

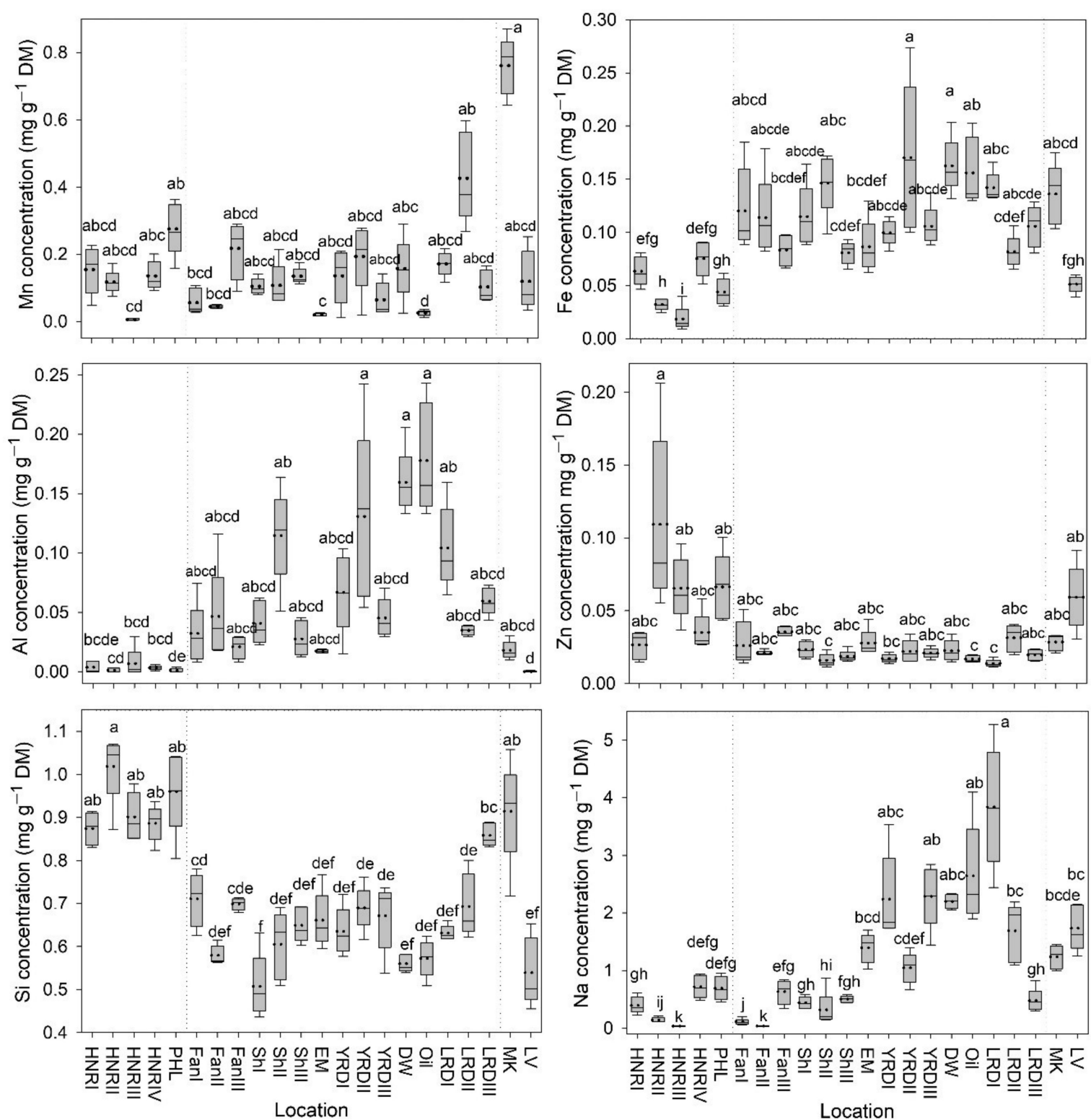

Figure 5. Shoot silicon $(\mathrm{Si})$, zinc $(\mathrm{Zn})$, aluminum $(\mathrm{Al})$, sodium $(\mathrm{Na})$, manganese $(\mathrm{Mn})$, and iron $(\mathrm{Fe})$ concentration of $P$. australis harvested in different provenances (left group from USA, center group from China, right group from Denmark). Boxplots with 25th to 75th percentile in box, whiskers with minimum and maximum values, median as solid line, and means indicated by stippled line $(\mathrm{n}=5)$. Different lowercase letters indicate statistically significant differences according to $95 \%$ Bonferroni intervals.

Spearman rank correlations revealed that several of the investigated tissue and morphological traits were significantly correlated, as shown in Figure 7. Shoot height and diameter, leaf number, leaf dry and fresh mass, and stem dry mass were strongly positively correlated. All or most of those morphological parameters showed also positive correlations with tissue ions such as $\mathrm{Zn}, \mathrm{Si}, \mathrm{Ca}, \mathrm{S}$, and N. Al, Fe, and Na were negatively correlated with biomass and morphology. Ash content was positively correlated with leaf number and dry and fresh mass, as well as shoot $\mathrm{Si}, \mathrm{Zn}, \mathrm{Ca}, \mathrm{S}$, and $\mathrm{N}$ concentrations. $\mathrm{Na}$ and $\mathrm{C}$ concentration correlated negatively with ash. Several ions had strong positive or negative correlations, such as $\mathrm{Na}$ with most macronutrients (negative) and $\mathrm{Al}$ with $\mathrm{Ca}, \mathrm{P}, \mathrm{S}$, $\mathrm{N}, \mathrm{Si}$, and $\mathrm{Zn}$ (negative), as well as $\mathrm{Ca}$ with $\mathrm{Mg}, \mathrm{S}, \mathrm{Zn}, \mathrm{Si}$, and $\mathrm{N}$ (positive). 


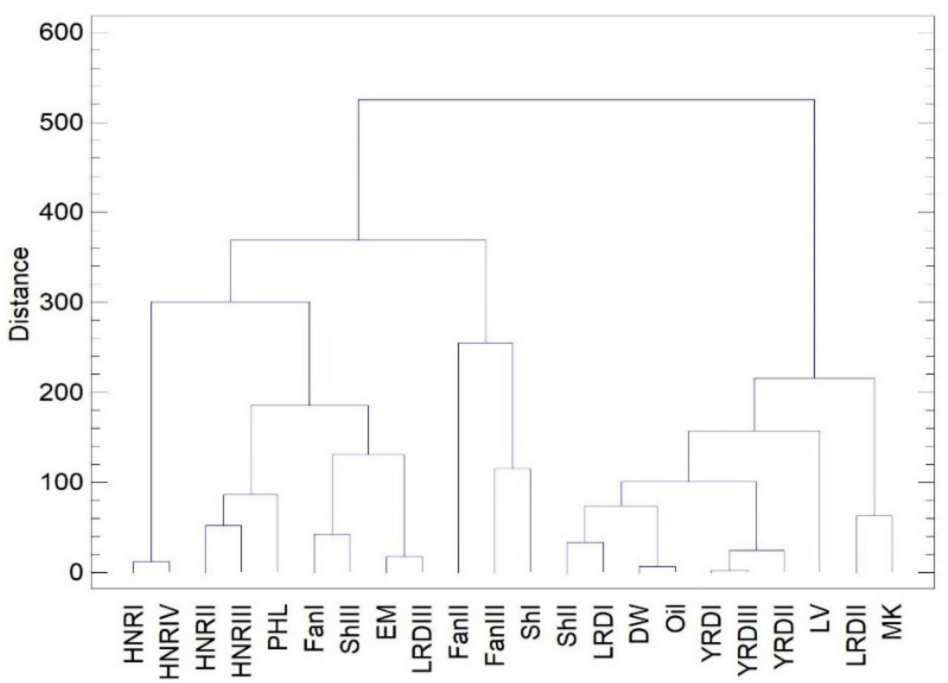

Figure 6. Dendrogram of $P$. australis clustered by Ward's minimum variance method according to population provenances (five from USA, 15 from China, two from Denmark), showing squared Euclidian distances.

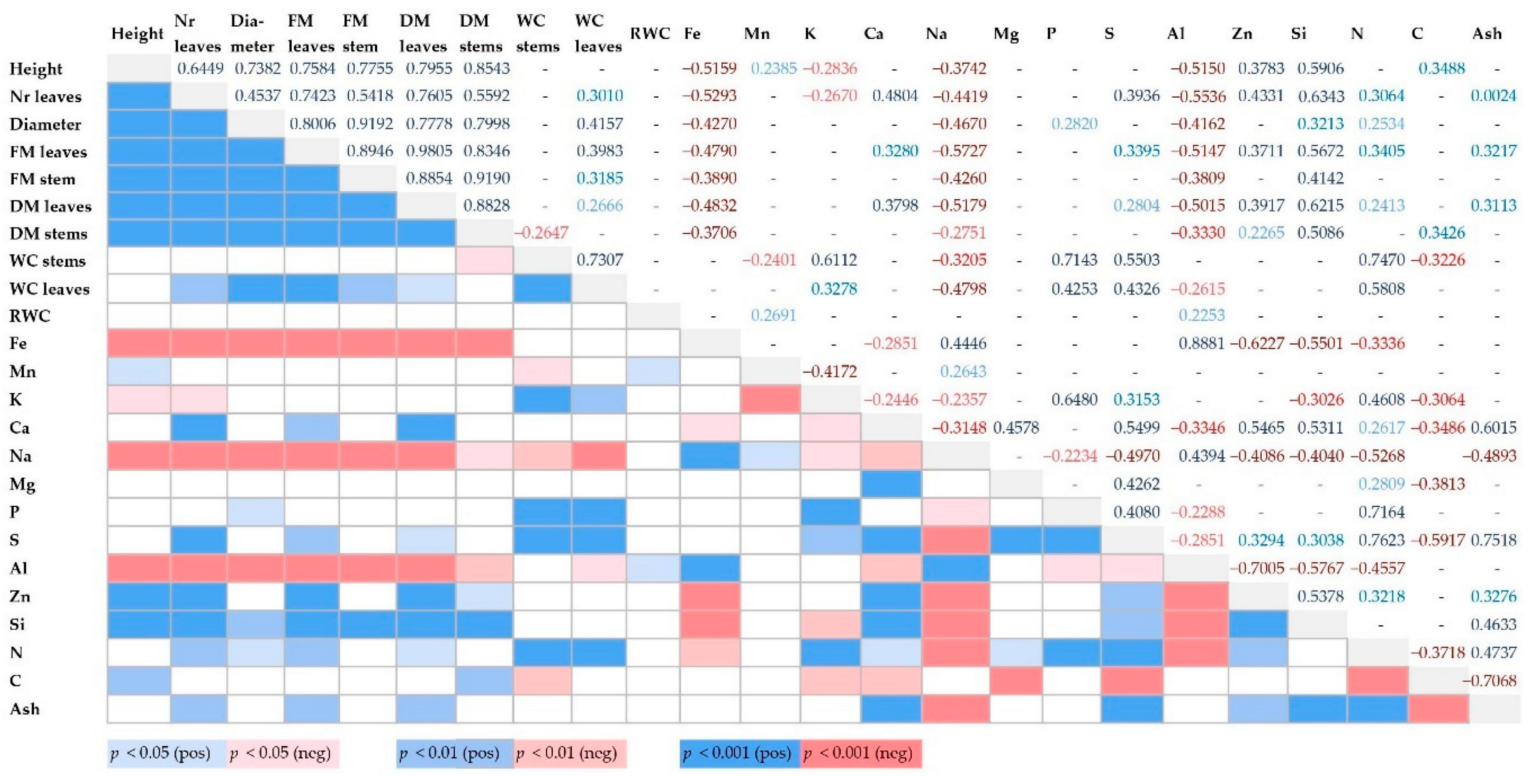

Figure 7. Spearman rank correlation coefficients of morphological and tissue characteristics of P. australis from different provenances. Nonsignificant coefficients are shown as white boxes.

\section{Discussion}

The utilization of biomass fuels as substitute for fossil fuels, for heat and other energy generation, relies on biomass characteristics such as the heating value, moisture content, elemental composition, and ash properties [4]. To estimate the suitability of P. australis biomass for bioenergy, we collected reed shoots from marsh locations in Denmark, the US, and in China, and measured different shoot growth parameters and the shoots' tissue nutrient concentration, water, and ash content. The analyzed parameters clustered in two main groups: reeds from the US and China, and reeds from Denmark and China. Reeds from the US were overall taller, with more leaves and greater culm biomass, and had greater shoot diameters, than reeds from the other provenances. The US plants all belonged to an invasive lineage previously introduced from Eurasia, which can be recognized by its densely growing monoculture stands, rigid tall culms, and dark green leaves [38,39]. Although European P. australis are the source populations of the invasive reeds in North America, they are not as tall and vigorous as 
their US counterparts, including the here investigated Danish reeds. Post-introduction adaptation is likely to have occurred and increased the assimilation efficiency and competitiveness of the invasive reeds [43]. Although the vigor of invasive reed is highly problematic ecologically, attempts to control its establishment are not without consequences either. Thus, management may be extremely difficult since the native flora is unlikely to be completely restored to the pre-invasion ecosystems, and mowing and herbicide treatment may alter habitat structure and result in indirect trophic alterations [44,45]. The application of invasive reed in North America as biofuel pellets has previously been shown to be similar in quality to switchgrass (Panicum virgatum), a cultivated bioenergy crop [46], which is a promising outlook for reed biomass as bioenergy feedstock.

Stems and leaves of reeds had high water content, with equal or higher amounts of water than dry mass in most populations. Biomass harvested for anaerobic digestion requires drying as pre-treatment, which will cost more energy in moister tissues $[47,48]$. The shoots with the highest moisture content originated in Fanggan and Shandong, but overall, the water content did not appear to result from different ecosystem water availabilities. Since leaves analyzed for RWC were relatively young, leaf age may be a possible explanation for the high water content, a phenomenon that has previously been described in other species [49]. Although biomass moistness was expected to be lower in the brackish and saline estuaries and in the heavily impacted oil fields in the Chinese populations [41], the freshwater populations from US and Denmark were not found to be accordingly higher. Furthermore, RWC barely differed between populations, showing that all plants maintained close to fully hydrated leaves in any ecosystem [41]. The extensive root network of reed is likely to reach deep water sources, which grants access to fresh water but also nutrients outside the depletion zone [50]. The rhizomatous integration of shoots allows reed to transport nutrients and assimilates over longer distances to more remote shoots [51,52]. Hence, the nutrient availability status of the plants is better reflected by tissue nutrient concentrations than soil nutrient content, which can be very heterogeneous [53].

The here reported shoot diameters are at the high end of the spectrum (mean from 5.4 to $9.0 \mathrm{~mm}$ ), while formerly investigated thatching reeds from different European countries and China were generally thinner (mean diameter between 2.4 and $7.7 \mathrm{~mm}$ ) [48]. Plant biomass can be quantified using allometry between shoot diameter and shoot height, a non-invasive estimation technique commonly used in plant ecology [54]. Allometric relationships are linear; hence, the larger the diameter and the taller the shoots, the more biomass a plant is producing, which translates our data into promising productivity, especially for reeds from the US.

Despite the clear difference in biomass parameters, the tissue nutrient concentrations varied to a great extent, between, but also within, populations. This variability results from multiple influential factors both in the environment, but probably also in the genetic constitution of the populations and the single genotypes [26,32]. Numerous studies have shown reed growth responses to different nutrient availability, most of them demonstrating that reed prefers eutrophic conditions and generally integrates more nutrients in its tissues with increasing nutrient concentration in the soil [6,55]. Specific tissue properties may be needed for specific energy purposes, which may limit the applicability of certain populations. During combustion, for example, several chemical and physical changes of the minerals at high temperature occur. $\mathrm{Si}$, the main ash-forming element, will melt and interact chemically with other components to form alkali metal silicates. Elements including $\mathrm{Si}, \mathrm{K}, \mathrm{Na}, \mathrm{S}, \mathrm{P}, \mathrm{Ca}, \mathrm{Mg}$, and Fe are involved in reactions leading to corrosion, ash fouling, and slagging, which will also depend on combustion conditions like burner-technology $[4,56]$. P concentrations found in our study were within the range to somewhat higher than previously detected in reed biomass [57]. $\mathrm{Zn}$ is a heavy metal, acting as aerosol-forming element that can increase particle emissions during combustion [58]. The mean $\mathrm{Zn}$ concentrations in our analyzed populations were below the threshold value for wood briquettes or pellets to be used in the European Union [58].

$\mathrm{N}$ in plant tissue is mainly part of proteins and other, easily degradable compounds [59]. The $\mathrm{N}$ concentration is usually highest in leaves, although the $\mathrm{N}$ concentrations in the analyzed samples were comparably low $[10,57]$. Low $\mathrm{N}$ could pose a challenge to biomethane production or biomass harvest 
for nutrient removal. More eutrophic habitats than the ones included in our study can be found with large, natural reed monocultures. Those should be targeted if higher tissue $\mathrm{N}$ concentration is desired. Moreover, biomass produced earlier in the growing season is usually richer in $\mathrm{N}$ than late-season biomass, due to a re-allocation of $\mathrm{N}$ to the panicles $[59,60]$. Reed has previously been shown to be efficient feedstock for biomethane production, so choosing an adequate harvest time is crucial for obtaining optimal biomass properties for that specific purpose [3,10,47,57,61,62].

If the biomass is intended to be used as solid biofuel, the $\mathrm{N}$ concentration, as well as $\mathrm{S}$ and $\mathrm{K}$, are preferred to be low, opposite to $\mathrm{Ca}$, which should be abundant, as it reduces the ash concentration [58]. Ca concentration was positively correlated with leaf biomass and number, hence, reeds with numerous leaves per shoot should be chosen for combustion, such as the populations from the US. The Ca concentration we found in the different reed populations are comparable to those previously found for crop straw used for biocombustion [58]. Ca was, however, positively correlated with other nutrients such as $\mathrm{S}$ and $\mathrm{N}$. Ca is taken up by the plant as cation, while $\mathrm{S}$ and $\mathrm{N}$ are mainly assimilated as anions. This leads to ion synergism, which is especially pronounced between cations and anions, resulting from the tendency of the cell to reach electrochemical balance between cations and anions. A high uptake of an anion like nitrate- $\mathrm{N}$ therefore leads to an enhanced uptake of cations like $\mathrm{Ca}$ [5].

Several other of the chemical components and morphological traits were correlated. Nitrogen and phosphorus were positively correlated, which is explained by the co-limited relative growth rate by both nutrients, although surplus of only one of the two components can lead to deficiency of the other [63]. In general, availability of nutrients to plants allows for high productivity, which explains the many positive correlations detected between morphological traits and minerals. Those correlations can be expected in biomass harvested during the growing season, as has been shown also for root minerals and biomass [64]. Biomass harvested during winter will have weaker correlations between minerals but constant morphological parameters, since nutrient concentrations in aboveground biomass change during seasons [48]. Exceptions to this positive relationship were $\mathrm{Na}, \mathrm{Al}$, and $\mathrm{Fe}$, which are toxic in high concentrations. High soil salinity (i.e., high $\mathrm{Na}$ ) is detrimental to reed germination, and high $\mathrm{Ca}$ concentration has been shown to reverse this effect and alleviate $\mathrm{Na}$ impacts [65]. The critical toxicity concentration of Fe has been determined to be $0.15 \mathrm{mg} \mathrm{g}^{-1}$ dry mass for reeds of different origin [32], which is average or even lower than the tissue concentrations we found, explaining the negative correlation of Fe with all growth parameters. The $\mathrm{Al}$ concentrations varied, but most shoots had low concentrations close to detection limit.

The heating value is indicative of thermal conversion of biomass during combustion. Heating values have been shown to be negatively correlated with ash content after burning, with desirable ash content under $10 \%$ [66]. All of the here investigated reed populations can be estimated to have high heating values, if merely ash content is considered, and hence, contain a suitable biomass fuel energy content. Moreover, $\mathrm{C}$ concentration is positively correlated with heating values, and the here presented data for $\mathrm{C}$ concentration lie well within the average of organic biomass sources [66]. Reed populations from the Mediterranean area have previously been shown to have even lower ash concentrations, so this characteristic seems to be rather variable between global populations [10]. Different biomass sources, like weeds or agricultural residues, have ash concentrations varying from $0.8 \%$ to $8.7 \%$ [2], which is similar to the studied reeds, which ranged from $3.9 \%$ to $8.5 \%$.

Sustainable bioenergy species have, amongst other qualities, relatively low levels of ash, high productivity with low inputs of fertilizer or other chemicals, and grow on land with little or no alternative value $[67,68]$. Our analyses show that reed populations from different areas have most of the properties an ideal bioenergy species should possess. We harvested shoots during the peak of the growing season, to analyze biomass produced at the maximum growth rates. However, harvest for combustion or construction requires dry biomass and therefore takes place during wintertime. The nutrient concentrations can be anticipated to be different in winter-harvested biomass, with mobile nutrients, such as $\mathrm{N}$ or $\mathrm{Mg}$, being recycled to the rhizomes [48,61]. Fresh biomass is usually harvested for biogas production, since the ideal $\mathrm{C} / \mathrm{N}$ ratios for biomethane are comparably low [10]. 
Fresh plant material is also taken if nutrients are to be removed from the ecosystem to counteract eutrophication and possibly redistribute the nutrient-rich biomass as fertilizer, a management approach previously suggested for invasive plants [57]. Harvesting reed for bioenergy is therefore a promising sustainable way to obtain biomass, as reed is a renewable resource due to its vast belowground biomass. Roots extending up to $95 \mathrm{~cm}$ soil depths ensure acquisition of nutrient and freshwater resources, while the extensive network of rhizomes guarantees starch storage for overwintering and asexual propagation, even if the aboveground culms are cut $[50,69,70]$. We found that the tissue quality depended largely on local conditions, and did not differ due to provenance, in contrast to the shoot morphological traits, which were highest for US reeds. Utilizing biomass from wetland plants such as reed is sustainable not only because its bioenergy potential is high, but also because maintaining wetlands for biomass production will contribute to nature conservation and a plethora of ecosystem services [71]. Local policies for biomaterial will need to be integrated in future long-term studies on biomass production of reed as an alternative energy source to fossil fuel.

Author Contributions: Conceptualization, F.E.; methodology, F.E., X.G., and T.J.M.; software, F.E.; validation, F.E. and H.B.; formal analysis, F.E.; investigation, F.E., X.G., S.Y., and T.J.M.; resources, F.E., X.G., S.Y., T.J.M., and H.B.; data curation, F.E.; writing —original draft preparation, F.E.; writing-review and editing, X.G., S.Y., T.J.M., and H.B.; visualization, F.E.; supervision, H.B.; project administration, F.E.; funding acquisition, F.E. and S.Y. All authors have read and agreed to the published version of the manuscript.

Funding: This research was funded by CARLSBERG FOUNDATION, grant number CF15-0330. S.Y. was funded by the National Key R\&D Program of China, grant number 2016YFE0109600.

Conflicts of Interest: The authors declare no conflict of interest.

\section{References}

1. Zhang, P.; Zhang, L.; Chang, Y.; Xu, M.; Hao, Y.; Liang, S.; Liu, G.; Yang, Z.; Wang, C. Food-energy-water (FEW) nexus for urban sustainability: A comprehensive review. Resour. Conserv. Recycl. 2019, 142, $215-224$. [CrossRef]

2. Pandiyan, K.; Singh, A.; Singh, S.; Saxena, A.K.; Nain, L. Technological interventions for utilization of crop residues and weedy biomass for second generation bio-ethanol production. Renew. Energy 2019, 132, 723-741. [CrossRef]

3. Mayer, F.; Gerin, P.A.; Noo, A.; Lemaigre, S.; Stilmant, D.; Schmit, T.; Leclech, N.; Ruelle, L.; Gennen, J.; von Francken-Welz, H.; et al. Assessment of energy crops alternative to maize for biogas production in the Greater Region. Bioresour. Technol. 2014, 166, 358-367. [CrossRef] [PubMed]

4. Jenkins, B.M.; Baxter, L.L.; Miles, T.R.; Miles, T.R. Combustion properties of biomass. Fuel Process. Technol. 1998, 54, 17-46. [CrossRef]

5. Marschner, H. 13-Nutrient Availability in Soils. In Mineral Nutrition of Higher Plants, 2nd ed.; Marschner, H., Ed.; Academic Press: London, UK, 1995; pp. 483-507. ISBN 978-0-12-473542-2.

6. Ren, L.; Eller, F.; Lambertini, C.; Guo, W.Y.; Brix, H.; Sorrell, B.K. Assessing nutrient responses and biomass quality for selection of appropriate paludiculture crops. Sci. Total Environ. 2019, 664, 1150-1161. [CrossRef]

7. Nunes, L.J.R.; Matias, J.C.O.; Catalão, J.P.S. Biomass combustion systems: A review on the physical and chemical properties of the ashes. Renew. Sustain. Energy Rev. 2016, 53, 235-242. [CrossRef]

8. Lessmann, J.M.; Brix, H.; Bauer, V.; Clevering, O.A.; Comin, F.A. Effect of climatic gradients on the photosynthetic responses of four Phragmites australis populations. Aquat. Bot. 2001, 69, 109-126. [CrossRef]

9. Eller, F.; Skálová, H.; Caplan, J.S.; Bhattarai, G.P.; Burger, M.K.; Cronin, J.T.; Guo, W.-Y.; Guo, X.; Hazelton, E.L.G.; Kettenring, K.M.; et al. Cosmopolitan species as models for ecophysiological responses to global change: The common reed Phragmites australis. Front. Plant Sci. 2017, 8. [CrossRef]

10. Dragoni, F.; Giannini, V.; Ragaglini, G.; Bonari, E.; Silvestri, N. Effect of Harvest Time and Frequency on Biomass Quality and Biomethane Potential of Common Reed (Phragmites australis) Under Paludiculture Conditions. BioEnergy Res. 2017, 10, 1066-1078. [CrossRef]

11. Geurts, J.J.M.; van Duinen, G.-J.A.; van Belle, J.; Wichmann, S.; Wichtmann, W.; Fritz, C. Recognize the high potential of paludiculture on rewetted peat soils to mitigate climate change. Landbauforschung 2019, 69, 5-8. [CrossRef] 
12. Wichtmann, W.; Couwenberg, J. Reed as a Renewable Resource and Other Aspects of Paludiculture Foreword. Mires Peat 2013, 13, 1-2.

13. Wichmann, S. Commercial viability of paludiculture: A comparison of harvesting reeds for biogas production, direct combustion, and thatching. Ecol. Eng. 2017. [CrossRef]

14. Brix, H. Genetic diversity, ecophysiology and growth dynamics of reed (Phragmites australis) -Introduction. Aquat. Bot. 1999, 64, 179-184.

15. Koppitz, H. Analysis of genetic diversity among selected populations of Phragmites australis world-wide. Aquat. Bot. 1999, 64, 209-221. [CrossRef]

16. Hansen, D.L.; Lambertini, C.; Jampeetong, A.; Brix, H. Clone-specific differences in Phragmites australis: Effects of ploidy level and geographic origin. Aquat. Bot. 2007, 86, 269-279. [CrossRef]

17. Eller, F.; Lambertini, C.; Nguyen, L.X.; Achenbach, L.; Brix, H. Interactive effects of elevated temperature and CO2 on two phylogeographically distinct clones of common reed (Phragmites australis). AoB Plants 2013, 5 , 1-13. [CrossRef]

18. Lambertini, C.; Gustafsson, M.H.G.; Frydenberg, J.; Lissner, J.; Speranza, M.; Brix, H. A phylogeographic study of the cosmopolitan genus Phragmites (Poaceae) based on AFLPs. Plant Syst. Evol. 2006, 258, 161-182. [CrossRef]

19. Klimeš, L. Phragmites australis at an extreme altitude: Rhizome architecture and its modelling. Folia Geobot. 2000, 35, 403-417. [CrossRef]

20. Bellavance, M.E.; Brisson, J. Spatial dynamics and morphological plasticity of common reed (Phragmites australis) and cattails (Typha sp.) in freshwater marshes and roadside ditches. Aquat. Bot. 2010, 93, 129-134. [CrossRef]

21. Saltonstall, K. Genetic variation among north American Populations of Phragmites australis: Implications for management. Estuaries 2003, 26, 444-451. [CrossRef]

22. Hauber, D.P.; Saltonstall, K.; White, D.A.; Hood, C.S. Genetic Variation in the Common Reed, Phragmites australis, in the Mississippi River Delta Marshes: Evidence for Multiple Introductions. Estuaries Coasts 2011, 34, 851-862. [CrossRef]

23. Lambertini, C.; Mendelssohn, I.A.; Gustafsson, M.G.H.; Olesen, B.; Riis, T.; Sorrell, B.K.; Brix, H. Tracing the origin of Gulf Coast Phragmites (Poaceae)—A story of long distance dispersal and hybridization. Am. J. Bot. 2012, 99, 538-551. [CrossRef] [PubMed]

24. Lambertini, C.; Sorrell, B.K.; Riis, T.; Olesen, B.; Brix, H. Exploring the borders of European Phragmites within a cosmopolitan genus. AoB Plants 2012, pls020. [CrossRef]

25. Nguyen, L.X.; Lambertini, C.; Sorrell, B.K.; Eller, F.; Achenbach, L.; Brix, H. Photosynthesis of co-existing Phragmites haplotypes in their non-native range: Are characteristics determined by adaptations derived from their native origin? AoB Plants 2013, 5, 1-13. [CrossRef]

26. Achenbach, L.; Eller, F.; Nguyen, L.X.; Brix, H. Differences in salinity tolerance of genetically distinct Phragmites australis clones. AoB Plants 2013, 5, 1-19. [CrossRef]

27. Kiviat, E. Ecosystem services of Phragmites in North America with emphasis on habitat functions. AoB Plants 2013, 5. [CrossRef]

28. Haslam, S.M. Early decay of Phragmites thatch: An outline of the problem. Aquat. Bot. 1989, 35, 129-132. [CrossRef]

29. Boar, R.R.; Kirby, J.J.H.; Leeming, D.J. Variations in the quality of the thatching reed Phragmites australis from wetlands in East Anglia, England. In Floodplains: Interdisciplinary Approaches; Marriott, S., Alexander, J., Eds.; Geological Soc. Publishing House: Avon, UK, 1999; Volume 163, pp. 145-151.

30. Nuamah, L.A.; Li, Y.; Pu, Y.; Nwankwegu, A.S.; Haikuo, Z.; Norgbey, E.; Banahene, P.; Bofah-Buoh, R. Constructed wetlands, status, progress, and challenges. The need for critical operational reassessment for a cleaner productive ecosystem. J. Clean. Prod. 2020, 269, 122340. [CrossRef]

31. Brix, H.; Ye, S.; Laws, E.A.; Sun, D.; Li, G.; Ding, X.; Yuan, H.; Zhao, G.; Wang, J.; Pei, S. Large-scale management of common reed, Phragmites australis, for paper production: A case study from the Liaohe Delta, China. Ecol. Eng. 2014, 73, 760-769. [CrossRef]

32. Ren, L.; Eller, F.; Lambertini, C.; Guo, W.Y.; Sorrell, B.K.; Brix, H. Minimum Fe requirement and toxic tissue concentration of Fe in Phragmites australis: A tool for alleviating Fe-deficiency in constructed wetlands. Ecol. Eng. 2018, 118, 152-160. [CrossRef] 
33. Ren, L.; Guo, X.; Liu, S.; Yu, T.; Guo, W.; Wang, R.; Ye, S.; Lambertini, C.; Brix, H.; Eller, F. Intraspecific variation in Phragmites australis: Clinal adaption of functional traits and phenotypic plasticity vary with latitude of origin. J. Ecol. 2020. [CrossRef]

34. Hazelton, E.L.G.; Mozdzer, T.J.; Burdick, D.M.; Kettenring, K.M.; Whigham, D.F. SPECIAL ISSUE: Phragmites australis in North America and Europe Phragmites australis management in the United States: 40 years of methods and outcomes. AoB Plants 2014, 6. [CrossRef]

35. Lambertini, C.; Guo, W.Y.; Ye, S.; Eller, F.; Guo, X.; Li, X.Z.; Sorrell, B.K.; Speranza, M.; Brix, H. Phylogenetic diversity shapes salt tolerance in Phragmites australis estuarine populations in East China. Sci. Rep. 2020, 10, 17645. [CrossRef]

36. Han, G.; Chu, X.; Xing, Q.; Li, D.; Yu, J.; Luo, Y.; Wang, G.; Mao, P.; Rafique, R. Effects of episodic flooding on the net ecosystem $\mathrm{CO}_{2}$ exchange of a supratidal wetland in the Yellow River Delta. J. Geophys. Res. Biogeosci. 2015, 120, 1506-1520. [CrossRef]

37. Ye, S.; Krauss, K.W.; Brix, H.; Wei, M.; Olsson, L.; Yu, X.; Ma, X.; Wang, J.; Yuan, H.; Zhao, G.; et al. Inter-Annual Variability of Area-Scaled Gaseous Carbon Emissions from Wetland Soils in the Liaohe Delta, China. PLoS ONE 2016, 11, e0160612. [CrossRef] [PubMed]

38. Swearingen, J.; Saltonstall, K. Phragmites Field Guide: Distinguishing Native and Exotic Forms of Common Reed (Phragmites australis) in the United States. Available online: http://www.nps.gov/plants/alien/pubs/ index.htm (accessed on 28 September 2020).

39. Saltonstall, K.; Peterson, P.M.; Soreng, R.J. Recognition of Phragmites australis subsp. americanus (Poaceae: Arundinoideae) in North America: Evidence from morphological and genetic analyses. SIDA 2004, 21, 683-692.

40. Barrs, H.D.; Weatherley, P.E. A Re-Examination of the Relative Turgidity Technique for Estimating Water Deficits in Leaves. Aust. J. Biol. Sci. 1962, 15, 413-428. [CrossRef]

41. Boyer, J.; James, R.; Munns, R.; Condon, T.; Passioura, J. Osmotic adjustment leads to anomalously low estimates of relative water content in wheat and barley. Funct. Plant Biol. 2008, 35, 1172-1182. [CrossRef]

42. Granato, D.; Santos, J.S.; Escher, G.B.; Ferreira, B.L.; Maggio, R.M. Use of principal component analysis (PCA) and hierarchical cluster analysis (HCA) for multivariate association between bioactive compounds and functional properties in foods: A critical perspective. Trends Food Sci. Technol. 2018, 72, 83-90. [CrossRef]

43. Guo, W.-Y.; Lambertini, C.; Nguyen, L.X.; Li, X.-Z.; Brix, H. Preadaptation and post-introduction evolution facilitate the invasion of Phragmites australis in North America. Ecol. Evol. 2014, 4, 4567-4577. [CrossRef]

44. Back, C.L.; Holomuzki, J.R.; Klarer, D.M.; Whyte, R.S. Herbiciding invasive reed: Indirect effects on habitat conditions and snail-algal assemblages one year post-application. Wetl. Ecol. Manag. 2012, 20, 419-431. [CrossRef]

45. Rohal, C.B.; Cranney, C.; Hazelton, E.L.G.; Kettenring, K.M. Invasive Phragmites australis management outcomes and native plant recovery are context dependent. Ecol. Evol. 2019, 9, 13835-13849. [CrossRef]

46. Vaicekonyte, R.; Kiviat, E.; Nsenga, F.; Ostfeld, A. An exploration of common reed (Phragmites australis) bioenergy potential in North America. Mires Peat 2013, 13, 1-9.

47. Eller, F.; Ehde, P.M.; Oehmke, C.; Ren, L.; Brix, H.; Sorrell, B.K.; Weisner, S.E.B. Biomethane Yield from Different European Phragmites australis Genotypes, Compared with Other Herbaceous Wetland Species Grown at Different Fertilization Regimes. Resources 2020, 9, 57. [CrossRef]

48. Woehler-Geske, A.; Moschner, C.R.; Gellerich, A.; Militz, H.; Greef, J.-M.; Hartung, E. Provenances and properties of thatching reed (Phragmites australis). Landbauforschung 2016, 66, 1-10. [CrossRef]

49. De Araujo, V.K.R.; da Silva, G.B.; de Lima Araújo, E.; de Mendonça Pimentel, R.M.; da Silva, K.A. Spatio-temporal variation in leaf morphofunctional attributes and relation to growth and survival of young woody plants. Braz. J. Bot. 2019, 42, 1-11. [CrossRef]

50. Moore, G.E.; Burdick, D.M.; Peter, C.R.; Keirstead, D.R. Belowground biomass of Phragmites australis in coastal marshes. Northeast. Nat. 2012, 19, 611-626. [CrossRef]

51. Haslam, S.M. Stem types of Phragmites communis Trin. Ann. Bot. 1969, 33, 127-131. [CrossRef]

52. Engloner, A.I. Structure, growth dynamics and biomass of reed (Phragmites australis) —A review. Flora 2009, 204, 331-346. [CrossRef]

53. Bates, T.E. Factors affecting critical nutrient concentrations in plants and their evaluation: A review. Soil Sci. 1971, 12, 116-130. [CrossRef] 
54. Lu, M.; Caplan, J.S.; Bakker, J.D.; Langley, J.A.; Mozdzer, T.J.; Drake, B.G.; Megonigal, J.P. Allometry data and equations for coastal marsh plants. Ecology 2016, 97, 3554. [CrossRef]

55. Geurts, J.J.M.; Oehmke, C.; Lambertini, C.; Eller, F.; Sorrell, B.K.; Mandiola, S.R.; Grootjans, A.P.; Brix, H.; Wichtmann, W.; Lamers, L.; et al. Nutrient removal potential and biomass production by Phragmites australis and Typha latifolia on European rewetted peat and mineral soils. Stoten 2020. [CrossRef] [PubMed]

56. Lewandowski, I.; Kauter, D. The influence of nitrogen fertilizer on the yield and combustion quality of whole grain crops for solid fuel use. Ind. Crops Prod. 2003, 17, 103-117. [CrossRef]

57. Carson, B.D.; Lishawa, S.C.; Tuchman, N.C.; Monks, A.M.; Lawrence, B.A.; Albert, D.A. Harvesting invasive plants to reduce nutrient loads and produce bioenergy: An assessment of Great Lakes coastal wetlands. Ecosphere 2018, 9, e02320. [CrossRef]

58. Kaltschmitt, M.; Hartmann, H.; Hofbauer, H. Energie aus Biomasse: Grundlagen, Techniken und Verfahren; Springer: Berlin/Heidelberg, Germany, 2009; ISBN 9783540850946.

59. Stitt, M.; Krapp, A. The interaction between elevated carbon dioxide and nitrogen nutrition: The physiological and molecular background. Plant Cell Environ. 1999, 22, 553-621. [CrossRef]

60. Mason, C.F.; Bryant, R.J. Production, nutrient content and decomposition of Phragmites communis Trin. and Typha angustifolia L. J. Ecol. 1975, 63, 71-95. [CrossRef]

61. Kandel, T.P.; Sutaryo, S.; Møller, H.B.; Jørgensen, U.; Lærke, P.E. Chemical composition and methane yield of reed canary grass as influenced by harvesting time and harvest frequency. Bioresour. Technol. 2013, 130, 659-666. [CrossRef]

62. Risén, E.; Gregeby, E.; Tatarchenko, O.; Blidberg, E.; Malmström, M.E.; Welander, U.; Gröndahl, F. Assessment of biomethane production from maritime common reed. J. Clean. Prod. 2013, 53, 186-194. [CrossRef]

63. De Groot, C.C.; Marcelis, L.F.M.; van den Boogaard, R.; Kaiser, W.M.; Lambers, H. Interaction of nitrogen and phosphorus nutrition in determining growth. Plant Soil 2003, 248, 257-268. [CrossRef]

64. Ksenofontova, T. Morphology, production and mineral contents in Phragmites australis in different waterbodies of the Estonian SSR. Folia Geobot. Phytotaxon. 1988, 23, 17-43. [CrossRef]

65. Zehra, A.; Gul, B.; Ansari, R.; Khan, M.A. Role of calcium in alleviating effect of salinity on germination of Phragmites karka seeds. S. Afr. J. Bot. 2012, 78, 122-128. [CrossRef]

66. Sheng, C.D.; Azevedo, J.L.T. Estimating the higher heating value of biomass fuels from basic analysis data. Biomass Bioenergy 2005, 28, 499-507. [CrossRef]

67. Madakadze, I.C.; Stewart, K.; Peterson, P.R.; Coulman, B.E.; Smith, D.L. Switchgrass Biomass and Chemical Composition for Biofuel in Eastern Canada. Agron. J. 1999, 91, 696-701. [CrossRef]

68. Delucchi, M.A. Impacts of biofuels on climate change, water use, and land use. Ann. N. Y. Acad. Sci. 2010, 1195, 28-45. [CrossRef]

69. Alvarez, M.G.; Tron, F.; Mauchamp, A. Sexual versus asexual colonization by Phragmites australis: 25-year reed dynamics in a mediterranean marsh, Southern France. Wetlands 2005, 25, 639-647. [CrossRef]

70. Haslam, S.M. The Development and Emergence of Buds in Phragmites communis Trin. Ann. Bot. 1969, 33, 289-301. [CrossRef]

71. Melts, I.; Ivask, M.; Geetha, M.; Takeuchi, K.; Heinsoo, K. Combining bioenergy and nature conservation: An example in wetlands. Renew. Sustain. Energy Rev. 2019, 111, 293-302. [CrossRef]

Publisher's Note: MDPI stays neutral with regard to jurisdictional claims in published maps and institutional affiliations.

(C) 2020 by the authors. Licensee MDPI, Basel, Switzerland. This article is an open access article distributed under the terms and conditions of the Creative Commons Attribution (CC BY) license (http://creativecommons.org/licenses/by/4.0/). 